Tropical Journal of Pharmaceutical Research, August 2009; 8 (4): 317-324

(C) Pharmacotherapy Group, Faculty of Pharmacy, University of Benin,

Benin City, 300001 Nigeria.

All rights reserved.

Research Article

Available online at http://www.tjpr.org

\title{
Anti-Cancer Properties of Diethylether Extract of Wood from Sukun (Artocarpus altilis) in Human Breast Cancer (T47D) Cells
}

\section{Enos Tangke Arung ${ }^{1,2}$, Britanto Dani Wicaksono1, Yohana Ayupriyanti Handoko', Irawan Wijaya Kusuma ${ }^{2}$, Dina Yulia and Ferry Sandra ${ }^{1^{*}}$}

${ }^{1}$ Stem Cell and Cancer Institute, Jalan Ahmad Yani no. 2 Pulomas, Jakarta, 13210, ${ }^{2}$ Wood Chemistry Laboratory, Forest Product Department, Forestry Faculty, Mulawarman University; Jalan KH. Dewantara, Kampus Gn. Kelua, Samarinda, East Kalimantan 75123, Indonesia.

\begin{abstract}
Purpose: To evaluate the anti-cancer properties of the diethylether extract of Sukun (Artocarpus altilis) wood.

Methods: The extract was tested in human T47D breast cancer cells and examined for its effect on cell viability, nuclear morphology and sub-G1 formation. Cell viability was determined by microculture tetrazolium technique (MTT), nuclear morphology investigated using 4'-6-diamidino-2-phenylindole (DAPI) staining technique, and cell cycle progression monitored by sub-G1 apoptosis assay using flow cytometry.

Results: The results showed decreasing cell viability in a concentration-dependent manner. Altered cell morphology after treatment with the extract demonstrated that cells experienced apoptosis. Cell cycle analysis indicated that the number of cells in sub-G1 phase rose with increasing concentrations of the extract.

Conclusion: The data demonstrate that Sukun wood extract induced apoptosis and sub-G1 phase formation in breast cancer (T47D) cells, and therefore, has a potential as an anti-cancer agent.
\end{abstract}

Keywords: Artocarpus altili; Diethylether extract; T47D cells; Anti-cancer; Apoptosis; Sub-G1 formation 


\section{INTRODUCTION}

For centuries, people have been using herbs for medicinal purposes. In fact, the use of herbal medicine can be traced back to at least 5000 years. Today, more than 85,000 plant species have been documented for medical use globally ${ }^{1}$. The World Health Organization (WHO) estimates that almost $75 \%$ of the world's population has therapeutic experience with herbal remedies ${ }^{1}$.

Artocarpus altilis, known as breadfruit, is a widely known food source but is also commonly used as a folk medicine in Indonesia where it is locally called Sukun. Traditionally, the leaves of Sukun are used for the treatment of various kinds of diseases such as liver cirrhosis, hypertension and diabetes $^{2}$. Scientifically, some biological activities of the extract of this plant have been reported. The methanol/dichloromethane extract from bud covers of sukun was shown to have activity in a cathepsin $\mathrm{K}$ inhibition assay $^{3}$. A study has reported that cathepsin $\mathrm{K}$ inhibitors are very effective in preventing bone resorption, and may, therefore, be a potential treatment option for osteoporosis ${ }^{4}$. The acetone extract of the leaves showed an inhibitory effect on $5 \alpha$-reductase activity which might make it useful for the selective treatment of benign prostate hyperplasia and prostate cancer ${ }^{5}$. Sukun extract has also been shown to alleviate the symptoms of diabetes mellitus and urinary problems ${ }^{6}$. Recently, a study showed the ethylacetate extract of the leaves had cytotoxic effects on some human cancer cell lines, including human lung adenocarcinoma (SPC-A-1 cells), human colon carcinoma (SW-480 cells), and human hepatocellular carcinoma (SMMC-7721 cells) $^{7}$, thus indicating that the extract might be a potential anti-cancer agent.

In this study, we have examined the anticancer properties of the diethylether (DE) extract of Sukun ( $A$. altilis) wood. Previous studies have shown that the DE extracts of the wood contain artocarpin, a prenylated flavonoid compound, which has various biological activities such as inhibition of $5 \alpha$ reductase $^{8,9}$ and melanin biosynthesis in B16 melanoma cells ${ }^{10}$. The activity of Sukun wood extract was assessed by investigating cell viability, observing the nuclear morphology of cells and examining the cell cycle process after treatment with Sukun wood extract.

\section{EXPERIMENTAL}

\section{Plant materials}

The wood of Artocarpus altilis was collected at Saramarinda City, Indonesia in 2006. The plant was identified by Raharjo, BSc. in the Dendrology Laboratory, Forestry Faculty, Mulawarman University, Indonesia and the voucher specimen (AK-CW-2) was deposited in the Wood Chemistry Laboratory, Forestry Faculty, Mulawarman University, Indonesia.

\section{Preparation of diethylether (DE) extract}

The DE extract of $A$. altilis wood was prepared according to the method previously described by Arung et al. ${ }^{10}$. The dried heartwood of $A$. altilis $(2.3 \mathrm{~kg})$ was cut into small pieces (approx. $0.5 \mathrm{~cm}^{3}$ ) and repeatedly extracted with methanol $(\mathrm{MeOH})$ at room temperature. The $\mathrm{MeOH}$ extract was concentrated using rotary evaporator under vacuum at room temperature to obtain a final residue $(60.6 \mathrm{~g})$. A portion of the extract (43.1 g) was suspended in $\mathrm{MeOH} /$ water (1:2) and partitioned with n-hexane, diethyl ether (DE) and ethylacetate (EtOAc). The DE soluble fraction was concentrated under vacuum at room temperature to obtain a final residue $(16.3 \mathrm{~g})$ for further tests. The extraction was conducted at the Wood Chemistry Laboratory, Forestry Faculty, Mulawarman University, Samarinda, East Kalimantan, Indonesia.

\section{Cell culture}

T47D cells were obtained from the Indonesian Institute of Sciences Research Centre for Chemistry, Natural Products, Food 
and Pharmaceuticals Division, Bandung, Indonesia. The cells were grown and maintained in Dulbecco's Modified Eagle's Medium (DMEM) with L-glutamine supplemented with $10 \% \mathrm{v} / \mathrm{v}$ foetal bovine serum, sodium bicarbonate, $100 \mu \mathrm{g} / \mathrm{ml}$ streptomycin and $100 \mathrm{U} / \mathrm{ml}$ penicillin at $37^{\circ} \mathrm{C}$ in a humidified atmosphere of $5 \% \mathrm{CO}_{2}$.

\section{Cell viability assay}

To determine cell viability, a microculture tetrazolium teachnique (MTT) assay was performed according to the method previously described by Arung et $a l^{11}$, with minor modifications. The MTT assay provides a quantitative measurement of viable cells by determining the amount of formazan crystals produced by metabolically active cells. Briefly, the cells were seeded into a 96-well plate $\left(5 \times 10^{3}\right.$ cells per well). After $24 \mathrm{~h}$ incubation, the medium was replaced with fresh medium containing Sukun wood extract, dimethyl sulfoxide ( $1 \% \mathrm{v} / \mathrm{v}$ DMSO in water), hydrogen peroxide $\left(0.07 \% \mathrm{v} / \mathrm{v} \mathrm{H}_{2} \mathrm{O}_{2}\right.$ in water $)$ or medium alone and the cells incubated for a further $24 \mathrm{~h}$. DMSO (1 \%v/v, in water) was used as a negative control since this was used to re-suspend the extract. MTT reagent [3-(4,5-dimethyl-2.thiazolyl)-2,5-

diphenyltetrazolium bromide $(10 \mu \mathrm{l})$ in PBS (5 $\mathrm{mg} / \mathrm{ml}$ )] was added to each well. The plate was incubated in a humidified atmosphere of $5 \% \mathrm{CO}_{2}$ at $37{ }^{\circ} \mathrm{C}$ for $3 \mathrm{~h}$, and then the medium was discarded and formazan crystals were dissolved in $1.0 \mathrm{ml}$ of $0.04 \mathrm{~N}$ $\mathrm{HCl}$. The absorbance of cells was measured at $570 \mathrm{~nm}$ with a microplate reader. Control cells were counted with a haemocytometer and used for interpolating the absorbance of MTT assay results. The data were presented as percent of viable cells (\%). The data were analyzed with the two-tailed student's $t$-test against samples treated with DMSO.

\section{Apoptosis measurements and DAPI staining}

In order to determine the level of apoptosis in cells, DAPI staining was performed as described by Sandra et al ${ }^{12}$. Briefly, the cells were seeded onto glass slides and treated with Sukun wood extract for $24 \mathrm{~h}$. Untreated and treated cells were rinsed with phosphate buffered saline (PBS), fixed with ice-cold 10\% trichloroacetic acid, and further washed with cold $70,80,90 \%$ and absolute ethanol. The cells were permeabilized with Triton-X (10 $\% \mathrm{v} / \mathrm{v})$ and stained with $1 \mu \mathrm{g} / \mathrm{ml}$ 4'-6diamidino-2-phenylindole (DAPI) for $3 \mathrm{~min}$. To reduce the background, the stained cells were washed with PBS, cover-slipped with 90\% glycerol and observed under a fluorescence microscope (Zeiss Axio Observer Z1, Göttingen, Germany).

\section{Sub-G1 apoptosis assay and flow cytometry}

The cells were separated into four treatment groups as stated for the cell viability assay above. The cells were analyzed for sub-G1 apoptosis using the method described by Sandra et $\mathrm{al}^{12}$. Briefly, the cells were seeded into a 24 -well plate ( $25 \times 10^{4}$ cells per well) and incubated for $24 \mathrm{~h}$. The medium was then replaced with fresh medium containing Sukun wood extract, DMSO, $\mathrm{H}_{2} \mathrm{O}_{2}$ or medium alone. After $24 \mathrm{~h}$, the cells were harvested and suspended in $1 \mathrm{ml}$ of hypotonic fluorochrome solution $(50 \mu \mathrm{g} / \mathrm{ml}$ propidium iodide in $0.1 \%$ sodium citrate containing 0.1 $\%$ Triton X-100). The cell suspensions were placed in the dark by wrapping up the tubes with aluminium foil and incubated at $4{ }^{\circ} \mathrm{C}$ for 1-2 $\mathrm{h}$ prior to flow cytometric analysis. The propidium iodide fluorescence of individual nuclei was measured using a FACS Calibur apparatus (Benton Dickinson, San Jose, California).

\section{High performance liquid chromatographic (HPLC) analysis}

The wood extract was filtered through a 0.22 $\mu \mathrm{m}$ syringe filter prior to analysis. Spectra were generated on a Waters ${ }^{\mathrm{TM}} 2487$ series HPLC (USA) equipped with a Waters ${ }^{\text {TM }} 1525$ binary HPLC pump and Millenium ${ }^{32}$ Photodiodide Array Detector (PDA). Data 
acquisition and treatment were performed with Empower 2 software. The separation was carried out at $25{ }^{\circ} \mathrm{C}$ on a $200 \mathrm{~mm} \times 4.6$ $\mathrm{mm}$ column packed with $5 \mu \mathrm{m}$ C18 (Symmetry, Waters). The mobile phase was methanol (85\%) and water (15\%) and delivered isocratically with a flow rate of 1.0 $\mathrm{ml} / \mathrm{min}$. The sample volume injected was 20 $\mu \mathrm{l}$. UV absorbance was measured at $254 \mathrm{~nm}$.

\section{Statistical analysis}

The $\mathrm{IC}_{50}$ (median inhibition concentration) is the concentration of toxic compound that reduces the biological activity by $50 \%$. The $\mathrm{IC}_{50}$ value was obtained from the MTT assay and calculated using non-linear regression analysis in Microsoft Excel software. The value was expressed as a geometric mean. Differences were considered to be statistically significant when $p<0.05$ and $p<$ 0.01 .

\section{RESULTS}

\section{Cytotoxic effects of Sukun wood extract in T47D cells}

Figure 1 shows the cell viability data obtained. There was a moderate decrease $(<$ $20 \%$ ) in cell viability when cells were treated with DMSO, the solvent used to re-suspend the extract. T47D cells treated with Sukun wood extract showed a decrease in viability in a concentration dependent-manner. Compared with those treated with DMSO, a significant decrease in cell viability $(p<0.01)$ was observed for T47D cells treated with 7.5 and $10 \mu \mathrm{g} / \mathrm{ml}$ of extract. $I_{50}$ was reached at a concentration of $6.19 \mu \mathrm{g} / \mathrm{ml}$.

\section{Nuclear morphology}

Based on the MTT assay results, DAPI staining was conducted to investigate whether Sukun wood extract induced apoptosis. Treatment of cells with Sukun wood extract at concentrations of 2.5 and 7.5 $\mu \mathrm{g} / \mathrm{ml}$, respectively, caused nuclear morphological changes compared to normal cells and this may be indicative of apoptosis (compare Figures 2B and $\mathrm{C}$ with Figure 2A). Morphological changes observed in the treated cells included cell shrinkage, nuclei that were broken into discrete fragments and cell budding (indicated by arrow) that resulted in cells of various sizes. Higher concentrations of Sukun wood extract appeared to cause more morphological changes, indicating that apoptosis occurred in a concentration-dependent fashion.

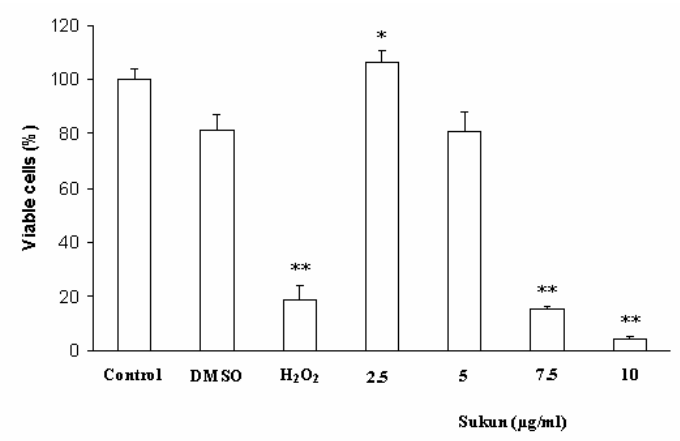

Figure 1: Effect of Sukun wood extract on T47D cell viability. (Treatments significantly differed from DMSO at ${ }^{*} p<0.05$ and $\left.{ }^{* *} p<0.01\right)$.
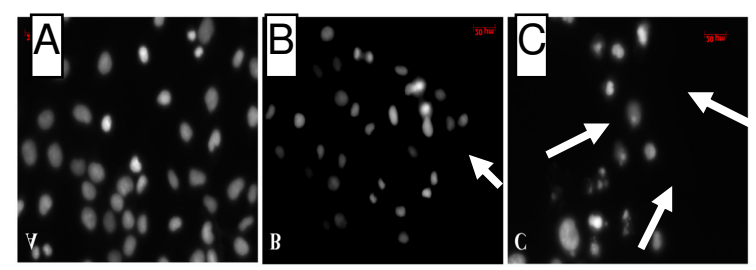

Figure 2: DAPI-stained T47D cells treated with Sukun extract. $\left(A=\right.$ untreated T47D cells $\left(1 \times 10^{4}\right)$; $\mathrm{B}=$ cells treated with Sukun wood extract at a concentration of $2.5 \mu \mathrm{g} / \mathrm{ml}$; and $\mathrm{C}=$ cells treated with Sukun wood extract at $7.5 \mu \mathrm{g} / \mathrm{ml}$. Arrows indicate apoptotic cells.)

\section{Sub-G1 apoptosis}

To understand the mechanism of inhibition of the Sukun wood extract, the effect of Sukun wood extract on cell cycle progression was analyzed by flow cytometry. In this experiment, $2.5,7.5$ and $10 \mu \mathrm{g} / \mathrm{ml}$ of Sukun wood extracts were used. Figure 3 shows that sub-G1 apoptotic content was markedly 
$\boldsymbol{A}$

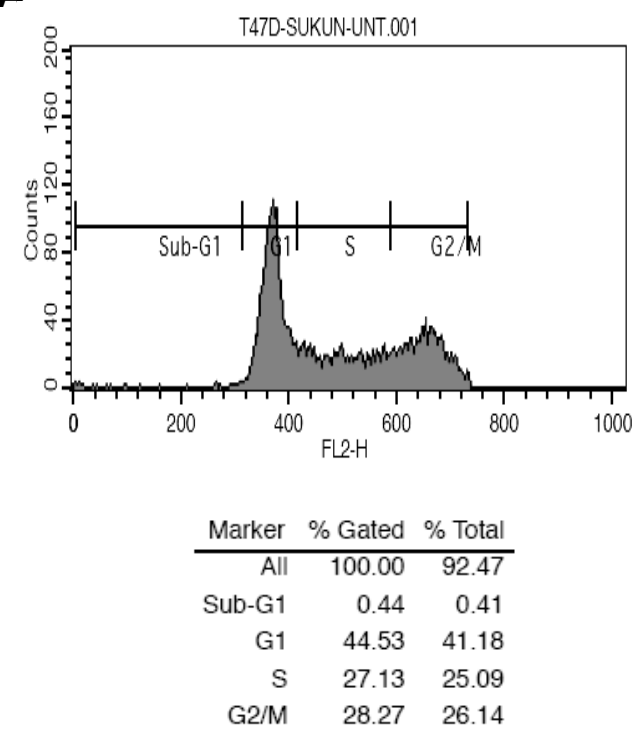

C

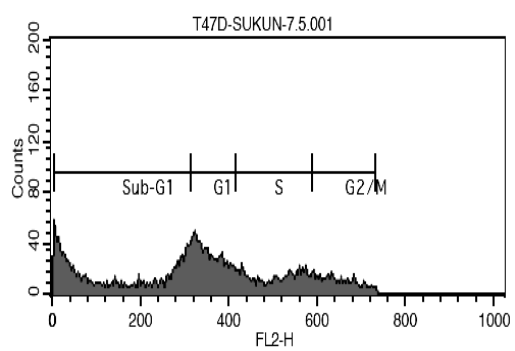

B

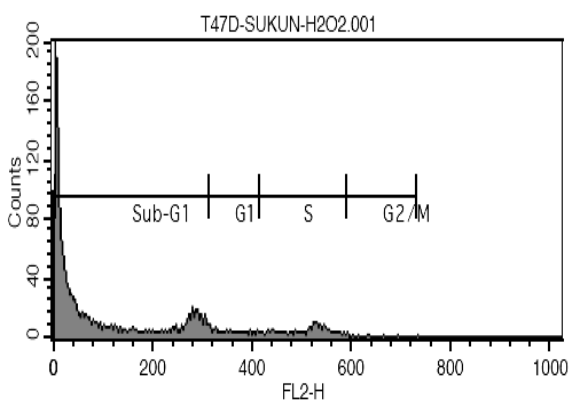

\begin{tabular}{rrr} 
Marker & $\%$ Gated & $\%$ Total \\
\hline All & 100.00 & 48.37 \\
Sub-G1 & 88.61 & 42.86 \\
G1 & 3.87 & 1.87 \\
S & 7.50 & 3.63 \\
G2/M & 0.23 & 0.11
\end{tabular}

D

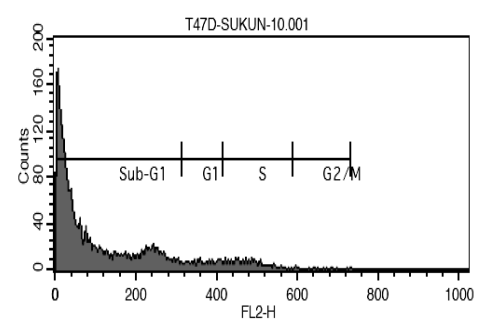

\begin{tabular}{rrr} 
Marker & $\%$ Gated & $\%$ Total \\
\hline All & 100.00 & 82.33 \\
Sub-G1 & 88.85 & 73.15 \\
G1 & 4.91 & 4.04 \\
S & 6.10 & 5.02 \\
G2/M & 0.27 & 0.22
\end{tabular}

Figure 3: Effect of Sukun wood extract on T47D cell cycle progression. $(A=$ untreated T47D cells $(25 X$ $\left.10^{4}\right) ; \mathrm{B}=$ cells treated with $\mathrm{H}_{2} \mathrm{O}_{2} ; \mathrm{C}=$ Sukun wood extract at a concentration of $7.5 \mu \mathrm{g} / \mathrm{ml}$; and $\mathrm{D}=$ Sukun wood extract at a concentration of $10 \mu \mathrm{g} / \mathrm{ml}$ ).

increased when cells were treated with Sukun wood extract. In the absence of the extract, sub-G1 was formed at $0.44 \%$ (Figure $3 A$ ), whereas a concentration of $7.5 \mu \mathrm{g} / \mathrm{ml}$ resulted in $39.74 \%$ of cells being in sub-G1 phase (Figure $3 \mathrm{C}$ ). This proportion of cells further increased at the extract concentration of $10 \mu \mathrm{g} / \mathrm{ml}(88.85 \%$, Figure 3D). This is similar to of the value for cells treated with $\mathrm{H}_{2} \mathrm{O}_{2}$ (88.61\%, Figure 3B). Therefore, an increase in the sub-G1 apoptotic fraction may be the major cause of reduced viability of T47D cells. 

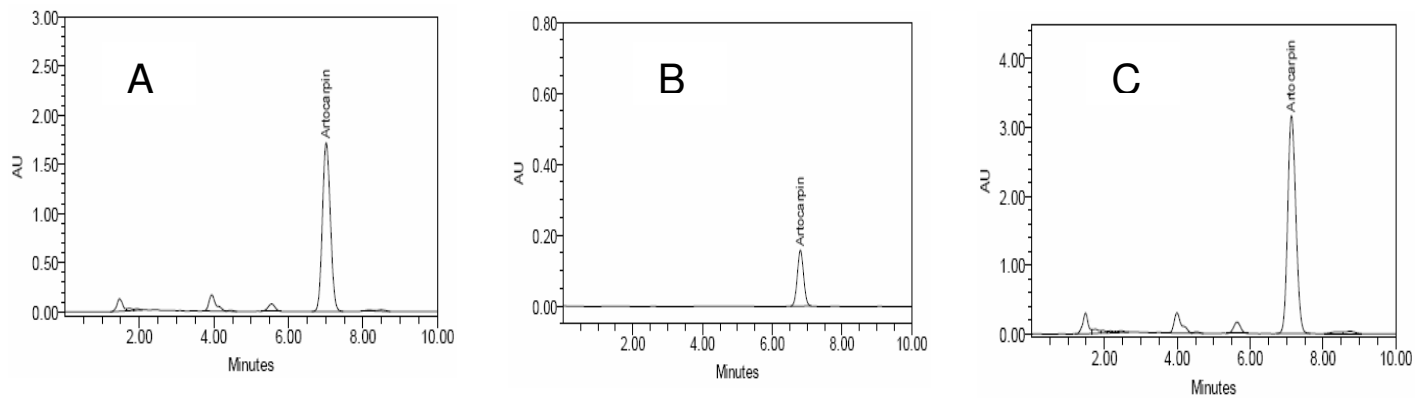

Figure 4: HPLC chromatogram of Sukun wood extract (A), artocarpin (B) and Sukun wood extract spiked with artocarpin (C)

\section{HPLC analysis}

To investigate the components present in Sukun wood extract, the extract was run in a HPLC. Four peaks were present in the extract and the primary peak appeared at approximately $7 \mathrm{~min}$ (Figure 4A). Previous studies have shown that the DE extract of $A$. altilis contained artocarpin $^{8-10}$. In this study, therefore, pure artocarpin, from the compound collections at Wood Chemistry Laboratory, Forest Product Department, Forestry Faculty, Mulawarman University, Samarinda, East Kalimantan, Indonesia, was run on a HPLC for comparison. Figure 4B shows that artocarpin peak was also produced at approximately 7 min. When the Sukun wood extract was spiked with pure artocarpin (Figure 4C), the main Sukun peak overlapped with the peak of pure artocarpin, indicating that the identity of the main Sukun peak was artocarpin.

\section{DISCUSSION}

Various plant extracts have been evaluated and shown to have cytotoxic or cytostatic effects in cancer cell lines. They include those of Solanum lyratum tested on human colon adenocarcinoma cell line (colo 205) ${ }^{13}$, Annona glabra on human leukemia cell lines $(\mathrm{CEM} / \mathrm{VLB})^{14}$, Gynostemma pentaphyllum on human lung cancer (A549) ${ }^{15}$ and Blumea balsamifera on rat and human hepatocellular carcinoma cells (McA-RH7777 and HepG2) ${ }^{16}$.
Previous studies on Artocarpus plants have shown various responses to extracts. Wang et al reported that five geranyl dihydrochalcones from the ethylacetate extract of $A$. altilis leaves had cytotoxic effects on some human cancer cell lines, such as human lung adenocarcinoma (SPC-A-1 cells), human colon carcinoma (SW-480 cells), and human hepatocellular carcinoma (SMMC-7721 cells). The results of our study show that Sukun wood extract has a cytotoxic effect on breast cancer cells (T47D) in a concentrationdependent manner, with an extract $\mathrm{IC}_{50} 6.19$ $\mu \mathrm{g} / \mathrm{ml}$. Our observations of altered nuclear morphology after treatment with the Sukun wood extract (Figure 2B andC) are consistent with previous reports of cells undergoing apoptosis. Kerr et al ${ }^{17}$ stated that characteristics of cells undergoing apoptosis include the formation of sharply delineated, uniformly fine granular masses adjacent to the nuclear envelope and cytoplasmic condensation; breaking up of the nucleus into discrete fragments surrounded by a double layered envelope; and cell budding to produce membrane-bounded apoptotic bodies. In line with morphological analysis, a sub-G1 apoptosis assay also confirmed that Sukun wood extract induced apoptosis in T47D cells in a concentration-dependent fashion (Figure $3 B, C$ and $D$ ).

The apoptotic effect of Sukun wood extract may be due to the presence of artocarpin, since this component was found to be the 
main compound in the extract (Figure 4). A similar finding that artocarpin, which was tested on other breast cancer cells, MCF-7 and MDA-MB-231, showed produced cytotoxicity effect with an $\mathrm{IC}_{50}$ of 3.3 and 3.8 $\mu \mathrm{g} / \mathrm{ml}$, respectively, has also been reported by Wang et $a 1^{18}$.

\section{CONCLUSION}

In this study, we found that Sukun wood extract, which primarily contains artocarpin, reduced cell viability by inducing apoptosis and sub-G1 phase formation in human breast T47D cells in vitro. This extract, therefore, has the potential of an anti-cancer agent. However, further study may still be necessary to elucidate the mechanism of apoptosis induction in T47D cells by Sukun wood extract.

\section{ACKNOWLEDGEMENT}

We acknowledge Ms Tjandrawati Mozef of the Indonesian Institute of Sciences Research Centre for Chemistry, Natural Products, Food and Pharmaceuticals Division, Bandung, Indonesia for generously supplying the T47D cells used in this work, and Dr Dyani Lewis of the School of Biological Sciences, Faculty of Science, Monash University, Australia for proof-reading this manuscript.

\section{REFERENCES}

1. Liu Y, Wang MW. Botanical drugs: challenges and opportunities: contribution to Linnaeus Memorial Symposium 2007. Life Sci, 2008; 82: 445-449.

2. Kasahara S, Hemmi S. Medicinal Herb Index In Indonesia. Bogor, Indonesia, PT. Eisal Indonesia, 1988, pp1-2.

3. Patil $A D$, Freyer $A J$, Killmer $L$, Offen $P$, Taylor $P B$, Votta $B J$, Johnson RK. A new dimeric dihydrochalcone and a new prenylated flavone from the bud covers of Artocarpus altilis: Potent inhibitors of cathepsin K. J Nat Prod, 2002; 65: 624-627.

4. Delaisse JM, Eackhout Y, Vaes G. Inhibition of bone resorption in culture by inhibitors of thiol proteinases. Biochem J, 1980; 192: 365-368.

5. Shimizu $K$, Kondo $R$, Sakai $K$, Buabarn $S$, Dilokkunanant U. 5 a-Reductase inhibitory component from leaves of Artocarpus altilis . J Wood Sci, 2000; 46: 385-389.

6. Lans, CA. Ethnomedicines used in Trinidad and Tobago for urinary problems and diabetes mellitus. J Ethnobiol and Ethnomed, 2006; 2; 45-56.

7. Wang $Y, X u K$, Lin L, Pan $Y$, Zheng $X$. Geranyl flavonoids from the leaves of Artocarpus altilis. Phytochem, 2007; 68: 1300-1306.

8. Shimizu K, Fukuda M, Kondo R, Sakai K. The $5 \alpha$ reductase inhibitory components from heartwood of Artocarpus incisus: structureactivity investigations. Planta Med, 2000; 66: 16-19.

9. Pitaksuteepong $T$, Somsiri A, Waranuch N. Targeted transfollicular delivery of artocarpin extract from Artocarpus incisus by means of microparticles. Eur J of Pharm Biopharm, 2007; 67: 639-645.

10. Arung $E T$, Shimizu $K$, Kondo R. Inhibitory effect of isoprenoid-substituted flavonoids isolated from Artocarpus heterophyllus on melanin biosynthesis. Planta Med, 2006; 72: 847-850.

11. Arung $E T$, Shimizu $K$, Kondo R. Inhibitory effect of artocarpanone from Artocarpus heterophyllus on melanin biosynthesis. Biol Pharm Bull, 2006; 29: 1966-1969.

12. Sandra F, Matsuda M, Yoshida H, Hirata M. Inositol hexakisphosphate blocks tumor cell growth by activating apoptotic machinery as well as by inhibiting the Akt/NFkappaB-mediated cell survival pathway. Carcinogenesis, 2002; 23: 2031-2041.

13. Hsu SC, Lu JH, Kuo CL, Yang JS, Lin MW, Chen GW, Su CC, Lu HF, Chung JG. Crude Extracts of Solanum lyratum Induced Cytotoxicity and Apoptosis in a Human Colon Adenocarcinoma Cell Line (Colo 205). Anticancer Res, 2008; 28 : 1045-1054.

14. Cochrane $C B$, Nair PK, Melnick SJ, Resek AP, Ramachandran C. Anticancer Effects of Annona glabra Plant Extracts in Human Leukemia Cell Lines. Anticancer Res, 2008; 28: 965-971.

15. Lu HF, Chen YS, Yang JS, Chen JC, Lu KW, Chiu $T H$, Liu KC, Yeh CC, Chen GW, Lin HJ, Chung JG. Gypenosides induced GO/G1 arrest via inhibition of cyclin $E$ and induction of apoptosis via activation of caspases-3 and -9 in human lung cancer A-549 cells. In Vivo, 2008; 22: 215221.

16. Norikura $T$, Kojima-Yuasa A, Shimizu M, Huang $X$, Xu S, Kametani S, Rho SN, Kennedy DO, Matsui-Yuasa I. Anticancer Activities and Mechanisms of Blumea balsamifera Extract in Hepatocellular Carcinoma Cells. Am J Chin Med, 2008; 36: 411-24.

17. Kerr, JFR, Winterford CM, Harmon BV. Apoptosis. Its significance in cancer and cancer therapy. Cancer, 1994; 73: 2013-2026.

18. Wang, YH, Hou, AJ, Chen L, Chen DF, Sun $H D$, Zhao QS, Bastow KF, Nakanish Y, Wang $X H$, Lee $K H$. New isoprenylated flavones, artochamins $A--E$, and cytotoxic principles from 
Arung et al

Artocarpus chama. J Nat Prod, 2004; 67: 757-

761.

Trop J Pharm Res, August 2009; 8 (4):324 